\title{
Between Narrativity, Memory, and Administration: Lists in Roman Historiography
}

Martin Stöckinger

Introduction: Lists as History, History as List

The relationship of lists, cultural memory, history, historiography, and narrativity has always been intimate. Let me start with an example of a text type with which most students of the humanities are familiar:

$\mathrm{BC}$

753 Legendary foundation of Rome

510 Traditional date of expulsion of kings and foundation of the Republic

270 Callimachus, Theocritus, Aratus active

100 Birth of Julius Caesar

84 Birth of Catullus

70 Birth of Virgil, 15 October

$[\ldots]$

M. Stöckinger $(\bowtie)$

University of Cologne, Bonn, Germany

e-mail: mstoecki@uni-koeln.de

(C) The Author(s) 2022

R. A. Barton et al. (eds.), Forms of List-Making: Epistemic, Literary, and Visual Enumeration, https://doi.org/10.1007/978-3-030-76970-3_2 
$\begin{array}{ll}43 & \text { Birth of Ovid, } 20 \text { March; death of Cicero } \\ {[\ldots]} & \\ 25 & \text { Ovid begins Amores } \\ {[\ldots]} & \\ \text { AD } & \\ 2 & \text { Metamorphoses and Fasti in progress } \\ {[\ldots]} & \\ 14 & \text { Augustus dies, succeeded by Tiberius } \\ 17 / 18 & \text { Death of Ovid in exile (Hardie 2002, 368-369) }\end{array}$

What we see here is a timeline from the final pages of a random academic book, in this case The Cambridge Companion to Ovid. The timeline spans from the foundation of Rome in $753 \mathrm{BCE}$ to Ovid's death in the year 17/18 CE. I have chosen this example to underscore the contrast it builds with my initial thoughts on the relationship between history, historiography, and lists. I began with the assumption that in any form of historiography, the predominant manner of treating lists of events would be to transform "chronicles" into narratives (i.e., "stories" and "plots") which in turn would create historical meaning, a phenomenon Hayden White has famously described as "emplotment." But what we find here is the opposite: these timelines at the end of modern academic books are conceived to reduce complexity after the author(s) have laid out their case in a prose narrative in the work itself. They ban and reduce the causalities between events into an assemblage of "pure facts." This is not to say that timelines of this kind do not have their own "narrativity" or "rhetoric," but they are obviously designed to serve as a more condensed, purer, less complex, and better manageable set of historical data than the narrative that precedes them in the book that they conclude. ${ }^{3}$ Students of the respective past, confused by or unfamiliar with the mass of information offered in the book, can find orientation in these lists. Mnemotechnics offers another case in point (think of examinees who prepare for a test and need a survey of the relevant material in a digestible form): history, in one of its most basic definitions, is the act of recording things, events, and persons that are worth being remembered, and lists can help with this, both on an individual and on a collective level.

In what follows, I will examine some functions of lists in Roman historiography. I use the term list in the sense of Robert Belknap's definition as a "framework $[\ldots]$ that holds separate and disparate items together" and "a formally organized block of information that is composed of a set of 
members" (Belknap 2004, 2 and 15). It is, of course, not possible to treat every Roman historian from every period. The compilation of a "list of lists in Roman historiography" would bring about the same problems as any list (such as completeness, selectivity, closure, and order) and, what is more, it would not be a very appealing endeavor, neither for its compiler nor for its reader. What we can say is that in antiquity, both in Greece and Rome with its late-antique successor provinces, lists feature prominently in commemorative practices from the earliest times on- a formulation that is meant to embrace historiography, but also other genres such as the epic and non-literary texts such as inscriptions as well as other media such as ancestral portrait galleries. ${ }^{4}$ Names of notable magistrates, rulers, priests, and persons regarded as exemplary, but also events, troops, provinces, monetary resources, and dispenses such as dedications, and so on, have often been collected and converted into lists, not seldom in their chronological sequence. By using and including lists, historiography mirrors this wider cultural commemorative practice to a certain extent.

In my analyses, I will focus on four examples, the first and the last of which (the Annales Maximi and Gregory of Tours) mark the margins of what we might call "Roman historiography," while the second and third, a passage from Tacitus' Histories and the Res Gestae Divi Augusti (RGDA), are selected from the early principate. Each of them comes with its own interpretive difficulties and a huge bulk of scholarship to which I can only refer selectively. I will start by examining the relationship between lists and historical narratives as introduced above. More specifically, I will demonstrate that this relationship can operate in two ways: whereas the traditional view (that lists lack causality) is present in Cicero's discussion of the Annales Maximi, Tacitus uses a list for the very purpose of explaining reasons and causes. The Tacitus example, which subtly grapples with an administrative list compiled by the emperor Augustus, will prepare the ground for the two sections to follow. Here I will argue that historical lists can be used to display political and religious power even beyond death: The RGDA consists of lists that, by the means of accumulation, create an effect of sublimity, thus intimating a bid for posthumous deification. Gregory closes his historical work with a list of the bishops of Tours, including himself as the then current bishop. On the one hand, this list is meant to secure his own fame as a religious leader and historian, yet on the other hand it remains open for continuation in order that Gregory's diocese might persist until the final days. 


\section{History Without Rhetoric: The AnNales Maximi (with Credits to Cicero)}

Perhaps the oldest form of written history in Rome was a list: the so-called Annales Maximi (literally the "greatest annals") ${ }^{5}$ were daily records written on a tablet by the chief priest in Rome, the Pontifex Maximus, and put on display at the priest's house. ${ }^{6}$ According to Servius, they contained "things worthy of mention which had been done at home and abroad, by land and sea, day by day" (Serv. Aen. 1.372-3 = FRHist T3). ${ }^{7}$ These records were collected and preserved in 80 books and were an invaluable source and point of reference for the Republican Roman historians until Livy.

But despite their dignity, the Annales Maximi soon became subject to severe criticism: Cicero says about them that "nothing could be more arid" (Cic. leg. 1.6 = FRHist T4 $)^{8}$ and, in another context on which I will focus in my argument, he complains that those Republican authors who wrote in the vein of the Annales Maximi present us with "records just of dates, persons, places, and events, which lack rhetorical adornment" (Cic. de orat. $2.53=$ FRHist T2). ${ }^{9}$ Today, our direct evidence for the Annales Maximi is very small: in his edition of the Fragments of the Roman Historians, Tim Cornell collects no more than six verified fragments and another six doubtful fragments of the Annales Maximi; in short, we are not in the position to judge whether or not Cicero's criticism is justified (Cornell 2013, vol. 2, 10-31).

What we can do is reconstruct Cicero's argument and its premises. One can wonder why Cicero introduces the category of rhetorical adornment here and, more importantly, what exactly he means when referring to the lack thereof. Within the context of this volume, narrativity and the role it plays therein are of particular importance. As an orator, Cicero is naturally interested in negotiating the relationship between historiography and rhetoric, that is, in the Roman context public political and juridical speech. An orator-be it in court or in a political debate-constantly has to construct narratives in order to convince his audience, and we know that the ancients were aware of this fact: in the traditional rhetorical taxonomy the central part of a speech, in which the argument is developed, is called narratio. ${ }^{10}$ The excerpt in question forms part of a longer passage (Cic. de orat. 2.51-64), ${ }^{11}$ in which Cicero, through his character Antonius, meditates on this relationship between historiography and rhetoric and, more precisely, on the question of how history should be written. ${ }^{12}$ Hence the 
introduction of rhetorical adornment as a category comes quite naturally and it is reasonable to suspect that narrativity does indeed play into it.

But what precisely is meant when Antonius complains about the lack of rhetorical adornment? Interestingly, not quite what we might associate with the term: Antonius contrasts Cato, Pictor, and Piso, whose writings are indebted to the list-like Annales Maximi, with Coelius Antipater, whom he counts under the exornatores rerum (Cic. de orat. 2.53-54). So we might assume that, in Cicero's and his characters' eyes, Coelius' style seems particularly beautiful-laden with rhetorical devices. Yet, in the next sentence, it emerges that both characters (Antonius and Catulus) agree on quite the opposite:

But even that Coelius of yours did not embroider his history with any variety of colouring nor did he give a finishing polish to his work by the arrangement of words or by a placid and uniform drawn-out style. [...] and yet, as you say, he did surpass his predecessors. (Cic. de orat. 54) ${ }^{13}$

In short, the elaboration which was intended to distinguish Coelius from the list-like Annales Maximi and from his predecessors who rely on these lists "has nothing to do with style," as Tony Woodman puts it; rather, "Antonius is talking about elaboration of content by means of content" (1988, 78; Woodman's italics).

As becomes clear in the sections to follow, the crucial element in this kind of elaboration is also a crucial element of narrativity in general: when Antonius propounds his theory on how history should be written he puts particular stress on the category of motivation, that is, of creating causality between otherwise isolated events. ${ }^{14} \mathrm{He}$ states that "it $[\ldots]$ requires $[\ldots]$ for the events a statement not only of what was done or said but also of how, and, when the outcome is discussed, that all the causes are explained, whether the result of chance, wisdom or recklessness" (Cic. de orat. 63). ${ }^{15}$

If we combine this phrase with his criticism of the list-like and in his words un-rhetorical Annales Maximi, we find that Cicero's view is not very original: Aristotle had already criticized the genre of historiography in general for relating actual-and we could add: contingent-events; poets, by contrast, narrate "events that might occur (be they actual or invented) [...] in terms of probability and necessity" (Arist. Poet. 1451b8-9). ${ }^{16}$ Gerrit Kloss has demonstrated that the Greek words for probability and necessity in this passage are exactly equivalent to what modern narratologists understand by "causality" or "motivation" (Kloss 
2003). For the sake of clarification, it should be noted that Aristotle's criticism of historiography relies on some false assumptions and is therefore erroneous: Greek and Roman historians of all times had a special interest in the causality of and between historical events, see for example, the programmatic passages by Herodotus (pref.) or Polybius (3.6.1-7 and 3.7.4-7), who make explicit use of the catchword aitía ("reason" /"cause"), as well as the remarks made by many other writers. ${ }^{17}$ But a lack of motivation in the Annales Maximi might be the reason why later Roman historians used these lists only as a source of historical facts (fundamenta "foundations" in Cicero's words, cf. Cic. de orat. 2.63) rather than a strict model for their own writing (exaedificatio "superstructure" in Cicero's words, cf. Cic. de orat. 2.63). This idea of quarrying historical data from a list and constructing causal relationships between them resembles and in a way anticipates Hayden White's theory of emplotment.

\section{Tacitus, Hist. 1.4-11 Between Logbook AND Causality}

My second example is also my first example from the imperial era. It is closely related to the Annales Maximi - a point to which I will turn in the middle of this section. At the beginning of his first major historical work, the Histories, Tacitus declares that he wants to lay out the number of Rome's troops and provinces, the state of the capital, and the surrounding nations, and so on (1.4.1). The passage features eight chapters (Tac. Hist. 1.4-11) and records a chronological retrospective and a geographical survey before Tacitus starts the account of his actual subject, that is, the events of the years from 69 (after the death of Nero) until the year 96, when Domitian died. Chapters 4-7 treat Rome, chapters 8-11 the provinces. $^{18}$

To start a historical work with a longer or shorter chronological retrospective is a traditional means of setting the ground for a historian's actual purpose, known from Thucydides and Sallust, and usually labeled as "archaeology." While chapters 4-7 of our passage seem not so innovative, the second half of the passage, that is, the survey of the military forces of the provinces in chapters 8-11, is more unusual. In Ronald Syme's words, "it lack[s] precedent or parallel in ancient historiography" (1958, 146, quoted in Damon 2003, 99). ${ }^{19}$ 
To be clear: to label Tacitus' passage a list in Belknap's sense as introduced above would be inaccurate. Admittedly, it amounts to slightly more than just "a framework that holds separate and disparate items together" in that it features brief story bits which prepare the main narrative. Yet these story bits are only loosely linked or even wholly unconnected, and so the label of list seems justified. To illustrate this, let us have a brief look at the beginning of the first half of the passage, which describes the state of affairs in Rome (status urbis) after the death of Nero:

Still, the senators were overjoyed, and promptly permitted themselves considerable freedom of speech in their negotiations with an emperor who was new to his task and absent from the capital. The leading members of the equestrian order were hardly less delighted than the senators. Hopes were raised among respectable Roman citizens who were connected to the great households, and among the dependants and freedmen of condemned men and exiles. The low-life types who had grown accustomed to the circus and theatres, the most villainous of the slave population and the squanderers who had been the recipients of Nero's degrading charity were gloomy and hungry for the latest rumours. (5) The city garrison (Tac. Hist. 1.4-5) ${ }^{20}$

Tacitus provides a survey of the different social classes in Rome. It features a top-down arrangement, starting with the highest rank, the senators, and ending with the lowest class, namely the slaves and the criminals, before turning to the military class in the following chapter. This conveys the impression of completeness - an important category of what Umberto Eco calls "practical lists." ${ }^{21}$ Of course, what we find here is only a guise of completeness: from the perspective of a modern historian, the list does contain its silences, if we think of women, children, or immigrants, all of which the city of Rome had many, to name but a few social groups which are not mentioned here. ${ }^{22}$ In his analysis of the social and political functions of lists, Urs Stäheli has worked out various techniques of inclusion and exclusion inherent to lists (Stäheli 2011, 2016); following up on Bruno Latour, he stresses the openness of lists, that is, their potential to be continued (2011, 93-95). As demonstrated above, a modern historian can indeed continue Tacitus' list. However, for the imperial historian himself (and perhaps for his audience), the list he provides is a closed one. In his striving for exactitude, Tacitus aims to cover the entire ground that he considers relevant before beginning his main narrative. 
In the second half of the passage, the geographical survey (Tac. Hist. 1.8-11), Tacitus also "provides far more than numbers of places," as Cynthia Damon has pointed out $(2003,99)$. Here he conveys the impression of completeness by giving a clockwise survey of the provinces around the Mediterranean, which starts in Spain, proceeds with the Gallic provinces, Germany, Upper Germany, Lower Germany, and Britain, then moves to Syria, Palestine, Egypt, and Africa, and ends by what I would call an et cetera-section of provinces which cannot be subsumed under the clockwise scheme. ${ }^{23}$

What is more, this list is related to an actual document, namely the breviarium totius imperii, a logbook, which Augustus as the first princeps had drafted himself and which after his death was handed down to his successors (see Tac. Ann. 1.11.3-4); Suetonius describes it as "an overview of the whole empire," the first half of which catalogues Rome's military resources. ${ }^{24}$ Tacitus, as a historian of the empire, works not so differently from Republican historians. While the latter often conceive parts of their works in relation to the Annales Maximi, Tacitus alludes to the form of the breviarium totius imperii, written by Augustus, who is not only the military and political ruler, but from 12 BCE onward also the Pontifex Maximus. The responsibility of the records of the state remains in the hands of the ruling class of Rome or, to put it differently, the administrative power over lists is identical with the political and religious power and has a great impact on Rome's cultural memory. ${ }^{25}$ By alluding to this actual administrative document, Tacitus shows an awareness of these entangled power relations - an aspect to which I will come back in the conclusion.

One final point about Tacitus' list: in my introduction and in the section on the Annales Maximi I have argued that lists of historical events lack causality. This is strikingly different in Tacitus: the narrative elements that constitute the list display a great amount of linguistic markers which insinuate, or at the very least prompt the reader to construct causality. By way of example I give a sentence we have already seen, this time in English and Latin:

the senators were overjoyed, and promptly permitted themselves considerable freedom of speech (i.e., 'since they had promptly permitted themselves considerable freedom of speech') in their negotiations with an emperor who (i.e., 'because the emperor with whom they negotiated') was new to his task and absent from the capital. 
sed patres laeti, usurpata statim libertate licentius ut erga principem nounm et absentem; (Tac. Hist. 1.4.3)

Two points are worth mentioning here: first, the fact that the emperor Galba was new in his office and absent from Rome is obviously set in relation to the senators' behavior in the negotiations (the notoriously polysemous conjunction $u t$ can be and has been read in a causal sense here). ${ }^{26}$ The translation by Wellesley revised by Ash which I have given (Welleslay and Ash 1995/2009) somewhat obscures the exact meaning; I have therefore inserted a more explicit translation in parentheses. Second, that the senators make use of their freedom of speech is expressed by an ablative absolute with a perfect participle (usurpata). Again, it is well possible to paraphrase this construction with a causal clause: the senators' use of their freedom of speech is a completed action at the time that they are overjoyed (laeti), and it is a reason for their joy. Moreover, the word statim ("promptly") suggests a "temporal antithesis" (Damon 2003, 102 ad loc.) to the time under Nero, further augmenting the senators' joy. So even in this short phrase, which is, I would argue, representative for the entire section, we already find at least two instances of causality:

- Emperor's absence and inexperience lead to the senators' freedom of speech.

- The senators' use of freedom of speech leads to their joy.

What is more, Tacitus states that he introduces the entire list specifically in order "to appreciate not only the actual course of events, whose outcome is often dictated by chance, but also their underlying logic and causes" (Tac. Hist. 1.4.1). ${ }^{27}$ In other words, Tacitus impugns the assumption that historical lists and causality exist on two separate continents. He makes use of the same terminology here as Cicero in the passage I have examined above (see n. 15 [Cic. de orat. 2.63 = FRHist T2] with n. 27: casus, euentus, causae). Cicero spoke of the tasks of a historian who does not confine himself to the list-like style of the Annales Maximi. Tacitus, however, uses these words to assert that his list is not a coincidental assemblage of contingent historical facts but a means to create causality. 


\section{The Sublime List of the Res Gestae Divi Augusti}

Augustus must have been very fond of lists, or so the breviarium totius imperii suggests. Perhaps even more famous is the so-called Monumentum Ancyranum or Res Gestae Divi Augusti (RGDA), an account of his achievements, which he claims to have written in the final year before his death (chapter 35). ${ }^{28}$ It was first published in the session of the senate following his death in the late summer of $14 \mathrm{CE}$. Augustus commissioned that it was carved on bronze tablets and put on display in front of his mausoleum in Rome, but later it received even wider circulation: the text came down to us on three temple inscriptions in Asia minor, the best preserved of which is found on the Temple of Augustus and Rome in Ankara, from which the Monumentum Ancyranum derives its name. The inscription is bilingual (Latin and Greek) and features no less than 35 chapters written in the first person plus an appendix of another four paragraphs written in the third person which summarizes the chapters. Theodor Mommsen therefore called the RGDA the "queen of ancient Latin inscriptions." 29

Its structure is complex: after a section on the honors (honores) which Augustus received (chapters 1-14), a larger section follows (15-35), in which his achievements (res gestae) and expenses (impensae) are intertwined. The text does not follow a clear-cut narrative scheme: there are only traces of chronology and scholars have therefore searched for other patterns. To highlight just two of the more recent and persuasive approaches, it has been suggested that the underlying principle of the text is the presentation of continuous moments of increase that chime in with the etymology of the name Augustus (< augeo "to increase," which is discussed in chapter 34); ${ }^{30}$ another interpretation lays particular stress on the interrelation of media (written text, monument, performance) which helps Augustus represent and consolidate his auctoritas. ${ }^{31}$ What we can say with certainty is that Augustus does not relate his achievements in a chronological sequence but groups them thematically. Categorization, which can ultimately lead to veritable taxonomies, has been a vital strategy of list-making in all periods (Eco 2009, 216-229, Mainberger 2013, 37-118.). Hence one can easily regard the inscription in its entirety as one massive list. This marks a crucial difference to the Tacitus example above: while Tacitus' Histories is a narrative that contains a list, the RGDA can be viewed as a list that contains some smaller narratives. If we look at the text 
more closely, we see that this list comprises in itself not only narratives but also various other lists, for example:

- Chapters 15-18: list of donations to the people of Rome and the veterans

- Chapters 19-21: list of buildings, renovations, dedications (mostly of temples) in the city of Rome

- Chapters 22-23: list of games

- Chapters 26-33: list of conquests (subdued provinces and rulers)

The text abounds with numbers and exact figures, most notably in the chapters on the monetary donations (15-18). To give a small but vivid impression about these accounts, let us have a look at chapter 15. Here Augustus lists the following sums which he donated over the course of the years: for the plebs 300 sesterces, two times 400 sesterces each, 12 grain rations, another 400 sesterces; for the urban plebs 60 denarii each; for the colonists 1000 sesterces each; and for the commoners 60 denarii. What is more, the list is peppered with the estimated numbers of beneficiaries of the donations: "never fewer than 250,000 members of the plebs" (15.1), " 320,000 members of the urban plebs" (15.2), "about 120,000 colonists" (15.3), and "200,000 commoners" (15.4). This account-holder mentality can also be found in the chapters on the games where Augustus meticulously records how often he arranged this or that game or where, for instance, he reports that in 26 hunting shows around 3500 wild African beasts were killed (22.3). ${ }^{32}$

Enumeration is an important formal principle in the $R G D A$; when we move to its contents, we see that exoticism is perhaps one of its most central issues. We have glimpsed that in the previous example of the hunting shows, but nowhere is this more palpable than in the section on Augustus' world conquest (26-33). Alison Cooley counts no less than "fifty-five geographical names, many of which must have sounded distinctly exotic to a Roman audience" (Cooley 2010, 36). Thus, Augustus presents himself as the conqueror of and ruler over the known world, following the footsteps of Alexander the Great. But this exoticism is conjoined with a great mass of information about Augustus' building activities in the city of Rome (19-21). ${ }^{33}$ We do not know whether Augustus had a diffusion of the text to the borders of the empire in mind, but just as the intended readership at his tomb in Rome could marvel at the exotic names, so too could readers in Asia marvel at the passages on the impressive architecture 
of the empire's capital. The main rhetorical feature of these lists is that of accumulatio: they gather a multitude of different items, thus expressing a great richness. But these accumulationes are hardly random; they have a clear goal in that they transcend the huge distances between the center and the periphery of the Roman empire and serve as a means to represent Augustus' power over urbs and orbis. ${ }^{34}$

Much ink has been spilled quarreling over the true motive behind the RGDA. Simple answers cannot be found, and it is well possible that Augustus had more than one ulterior motive behind the text. ${ }^{35}$ Perhaps the most attractive interpretation, which is shared by many scholars, is to read the $R G D A$ as a bid for posthumous deification. I would phrase this slightly differently: As a young man Augustus had written an autobiography; ${ }^{36}$ by writing the $R G D A$ shortly before his death, he renounces traditional narrative forms of this kind, which by introducing causality always involve interpretive elements and which are themselves subject to interpretation. Instead, he chooses the pure format of a list, which does not display explicit causal nexus between its elements. By doing so, Augustus allows the enumeration of his deeds speak for himself, thereby making himself independent from the decision of the senate or his successor: the immense list that is the $R G D A$, along with all its shorter constituent lists, constitutes an astounding personal monument notwithstanding the question of whether or not he was to be deified.

This interpretation is germane to, but not identical with the views brought forward by Jaś Elsner and Michèle Lowrie (see Elsner 1996 and Lowrie 2009, 279-309). Elsner stresses the RGDA's position on monuments and argues that the inscription conveys its imperial message particularly through its architectural, archaeological, and religious context (Elsner 1996, 49-53); Lowrie sees the iterability inherent in the medium of writing as the crucial element in fulfilling Augustus' desire for "selfperpetuation." ${ }^{37}$ I would argue that it is neither the monuments nor the medium of writing but the format of a list which does the talking. The $R G D A$, however, is not a list which functions as a tool to provide a neatly arranged survey much like the timelines I mentioned in the introduction. It does not transform the items it contains into a more manageable set of historical data; rather, the text functions as a vast accumulation of events which illustrate Augustus' grandeur. These events are carefully selected and ordered but constitute such a mass of information that it is not possible to absorb them all, especially not if one perceives them as an inscription and not as a text in a book. As such, I would argue they create an 
effect of sublimity. In his discussion of the mathematical sublime, Immanuel Kant defines that "the sublime is that in comparison with which everything else is small." "38 For Kant the sublime is closely linked to the idea of infinity, which is not explicitly present in $R G D A$ : its lists assemble many but not infinite honors and achievements; they cannot be continued endlessly. However-and this is the critical point-for Kant, sublimity lies not in the object per se but in the judging person's state of mind when perceiving the object: "We hence see also that true sublimity must be sought only in the mind of the [subject] judging, not in the natural Object, the judgement upon which occasions this state." 39

The sublime might be an interpretive key to the RGDA. On a general level, we can remind ourselves that the desire for deification that scholars suspect in the RGDA has areas of overlap with the idea of the sublime. In An Essay on the Sublime, John Baillie counts "desire of fame and immortality" under "the affections unexceptionably sublime" (Baillie 1747/2018, section III). When we return to the more specific Kantian concept of the sublime as introduced above, we can see the sublime's economic mechanisms at work: the huge sums of money in the chapters on the donations and dedications, the sheer mass of honors attributed to Augustus, the number of games over which he presided, and his building activities, conquests, and victories as presented in the RGDA are barely comprehensible in their own right, especially since the reader learns nothing about the causes and underlying intentions of these events. Despite the exact numbers and figures given in the text, these honors and achievements paradoxically elude any clear calculation, and a purely mathematical estimation becomes inadequate (one of Kant's key criteria). Taken together, all the different items contribute to Augustus' symbolic capital, yet they are not so easily - if at all-convertible into each other. From a strategical standpoint, the text purports to be an arid and wholly rational approach to the life of Augustus when in fact the RGDA overwhelms its readers by presenting an incomparable mass of prestigious accomplishments.

\section{Lists as Source and Sphragis in Gregory of Tour's}

\section{HISTORIA FRANCORUM}

Lists and catalogues remained important for historians throughout late antiquity and the early Middle Ages. This can be illustrated by Gregory of Tours' Historia Francorum, written in sixth-century Gaul, which has a 
great affinity to lists. ${ }^{40}$ Let us start with two examples from the second book: in 2.9 Gregory quotes from consular tablets, which in their original form were mere lists of names of the Roman consuls. ${ }^{41}$ Interestingly, Gregory seems to have found here more than a list of names, namely an elaborate narrative of at least two sentences, which contains the murder of King Theudemer and his mother Ascyla and the introduction of King Chlodio. After that, the reported speech breaks up, and we do not know from which sources Gregory has the information for the rest of his chapter. Only a few chapters later, a passage (2.18-19) remarkably interrupts the surrounding narrative of marvels and miracles and gives a rather dry and somewhat disruptive list of events of the 460s. It has therefore been suspected that in these two chapters Gregory reworks or even literally quotes annals of the city of Angers, a chronicle which also must have had a list-like format (Buchner 1990, XXXVI and $100 \mathrm{n} .1$ ). These two examples illustrate that in his historical research, Gregory, who made use of a great number of texts from various genres, obviously also consulted listlike formats. ${ }^{42}$

The most significant list in the Historia Francorum is the list of the bishops of Tours in the final chapter of the tenth book, which concludes the work (10.31). It is not very likely that Gregory compiled this list completely by himself. Rather, he may have found models in the archives which he could continue or at the very least use as a source. Nevertheless, as will become evident below, the insertion at the end of the historical work, and some other aspects, give this list an individual touch. We are dealing with a record of the 19 bishops of Tours from Catianus (\#1, 249-301 CE) to Gregory himself (\#19, $573 \mathrm{CE})$. Its form is modeled after the Liber Pontificalis, a chronicle of the popes, which had first been published some decades before Gregory's Historia Francorum (see Duchesne 1910, vol. $2,283)$.

A few things are remarkable here: first, like the list in $2.18-19$ briefly mentioned above, this list interrupts the flow of the narrative, but in a different manner, as it repeats and summarizes times and events that were related before. One might be willing to regard this list as a paratext in a vein similar to the timelines in modern academic books mentioned above.

But, and this is my second point, this would be a very special paratext, since it does not cover the entire time span which is treated in the Historia Francorum (which does not begin with the first bishop of Tours but with the creation of the world) and also because the dates and details given in this list are at times not in accordance with the preceding narrative. ${ }^{43}$ One 
can only speculate as to why this is the case. The most plausible answer is that Gregory made use of different sources which were themselves contradictory.

This leads to my third observation, namely that this list provides us with an interesting mix of narrative and list. Each section on a bishop can be regarded as a micro-narrative, or to put it more precisely, as a microbiography, sometimes written in the style of saints' legends. ${ }^{44}$ But frequently, these lists are nothing but accounts of achievements of the respective bishop or contain themselves various lists, which makes them comparable to the RGDA. For instance, we learn that Perpetuus (\#6) rebuilt the church over the tomb of St. Martin and founded five other churches. Moreover, he reorganized the order of fasts and feasts, which is presented in a list of 21 items. In short, Gregory's list of bishops is not only a list but in fact a "list of lists" or a "meta-list," so to speak. In the section about his own life (\#19), which closes the entire work in an autobiographic fashion, Gregory lists the churches he has built or renovated. What distinguishes him from his predecessors are his literary achievements, which can be listed: ten books of Histories, seven books of Miracles, one on the Lives of the Fathers, Commentaries on the Psalms, and a book on the Offices of the Church. Consequently, the end of Gregory's list can be read as a sphragis ("seal"), a traditional technique by which classical authors hint at their identity and literary achievements at the closure of their works.

This brief glance at the section about Gregory himself leads to a fourth and final point, namely that Gregory highlights that his list of bishops is not complete in a strict sense: it is complete at the very moment in which it is written, but since history continues, the list that records this history is to be continued as well.

Nevertheless I conjure you all, you Bishops of the Lord who will have charge of Tours cathedral after my unworthy self, I conjure you all, I say, [...], that you never permit these books to be destroyed, or to be rewritten, or to be reproduced in part only with sections omitted, for otherwise when you emerge in confusion from this Judgement Day you will be condemned with the Devil. Keep them in your possession, intact, with no amendments and just as I have left them to you. Whoever you are, you Bishop of God, even if our own Martianus Capella himself has given you instruction in the Seven Arts $[\ldots]$ and if, as a result, what I have written seems uncouth to you, despite all this, do not, I beg you, do violence to my Books. You may rewrite them in verse if you wish to, supposing that they find favour in your sight, but keep them intact. (Greg. Hist. 10.31) ${ }^{45}$ 
It is here that the indebtedness of Gregory's list to the Liber Pontificalis becomes palpable: for early historians of Christianity such as Gregory and the author(s) of the Liber Pontificalis, the history of the church is a history of (apostolic) succession. This principle is vital not only for Rome and the popes but also for smaller units of the Church such as the diocese of Tours. A list is the most natural format for relating this sort of succession history. It transfers the temporal sequence into a sequence that unfolds spatially on the final pages of Gregory's book. What is more, the list is a format which lends itself perfectly for continuation (see Stäheli 2011, 93-95): while it is true that Gregory's own time as bishop of Tours is the telos of both his History and its closing list, the list remains open to the future. And although Gregory shares a certain eschatological expectation with many contemporaries, even his following calculation of years, which reaches from the creation of the world down to the present day, must be regarded only as a subtotal. Gregory uses the open format of the list to secure and underscore the persistence of his diocese after his death until the Last Days.

Finally, Gregory makes some most interesting metaliterary claims here: by addressing both his successors as a group (omnes sacerdotes Domini, qui post me ...) and his immediate successor (o sacerdos Dei, quicumque es), he shows an awareness that he will not be the last bishop of Tours. The bishops after him will continue to write the history of his diocese. I deliberately choose the formulation of "writing history" here because it can be understood in two ways: Gregory's successors continue to "write" the history because they are the future of the diocese of Tours and, viewed from a later point, their names and achievements will be part of the list as $\# 20$, \#21, \#22, and so forth. On the other hand, Gregory seems to be aware that they too might "write" history in a very literal sense inasmuch as they will be in charge of the archives of the diocese (see Breukelaar 1994, 116-118). Gregory fashions himself and his successor bishops as similar to the Roman Republican Pontifices Maximi, as the keepers of both the religious sphere and the records of their community. Earlier, I suggested reading Gregory's list as a sphragis to his work. Having discussed Gregory's warnings, which are addressed to his successors, and thus look into the future, a slight amendment seems to be in order: we should rather, in an oxymoronic formulation, speak of Gregory's list as an "open seal." 


\section{Conclusion: The Social Life of Roman Historical Lists}

By way of conclusion I would like to stress three overarching aspects we have encountered in one way or another in the examples I have discussed. The first issue is so obvious that we barely reflect upon it, but it nevertheless merits some contextualization: it is the medium of writing on which all of the lists I have presented rely. The Annales Maximi and the RGDA are conceived as inscriptions, Tacitus' list playfully alludes to an actual document, namely Augustus' logbook of the empire, and Gregory, in his list of bishops, explicitly refers to his work as a piece of writing which is handed down to his successors and which may not be destroyed, cut, or shortened (see section "Lists as Source and Sphragis in Gregory of Tour's Historia Francorum"). As I have mentioned, we may not be all too surprised by this focus on writing, but we would do well to remind ourselves that lists can exist and have always existed in oral forms as well. ${ }^{46}$ Moreover, in recent years, scholars have stressed the oral aspects of the production, transmission, and performance of large parts of Latin literature, including historiography. ${ }^{47}$ While this movement is to some extent justified, the aspects of orality in Roman literature have been overstated to a certain extent. ${ }^{48}$ The texts I have presented in this contribution decidedly counteract the image of an oral Roman literature in that they put the role of writing front and center.

Closely related to the preeminence of writing is the role of bureaucracy, account keeping, and, most importantly, archives as stores of historical knowledge: of course, the Sitz im Leben of the production of the respective texts has changed in the transitions from the Republic to the age of Augustus, to the imperial, and finally to the early Christian medieval eras. But all authors discussed in this contribution certainly had access to, or were even responsible for, archives. The Pontifex Maximus was the keeper of the records of the state. Tacitus may not have examined the breviarium totius imperii with his own eyes, but as a member of the senatorial class he could ask for permission to examine the archives of the senate and read the so-called acta senatus and the acta diurna (see Schmal 2011, 108-111 and Woodman 2009, 8-10). Gregory as the bishop of Tours had access to the archive of his diocese and the scriptoria of the monasteries in the diocese. This means that on the one hand not everyone could have compiled the lists that I have discussed, but on the other hand it means that we have to rethink our notions of authorship of these lists, because each historical 
writer had to rely on information collected by others (predecessors in the respective office, secretaries, scribes, slaves, monks, etc.). In other words, we are dealing with forms of shared or collective authorship here.

Last but not least, we can see in all the lists that I have examined the intimate entanglement of memory and political power. From its beginnings until at least the times of Tacitus, Roman historiography was a project of the elite, which meant that members of the ruling class wrote history about themselves and for themselves (disclaimer: this does not mean that history could not be critical or polemic). We therefore label large parts of the historiographical production of this period as "senatorial historiography." Strikingly, more than 400 years later, Gregory of Tours preserved this model in the Gallic provinces. He, too, is a member of the senatorial (and now also episcopal) elite and essentially writes a history about and for his peers (see Breukelaar 1994, 116-132). Among my four examples, Tacitus is the only one to disentangle this relationship between political and administrative power on the one hand and memory on the other: by alluding to the logbook of the empire, he claims that he has the same wide and complete overview over the resources of Rome and its provinces as only the emperor and his secretaries can have, who themselves are in charge of this document (see Sailor 2007, 178-182). By composing his own list he opens the view for a different and I would say deviant perspective on a period of the imperial history of Rome and its causalities.

It is a fruitful, and for a literary critic perhaps the most natural way to examine lists in historiography vis-à-vis narratives. As demonstrated, these two formats always stand in one or another relation to each other and sometimes even overlap: lists which function as chronicles or datelines such as the Annales Maximi collect material for a more "elaborate" historical narrative; other lists like Tacitus' list in the Histories are embedded into or precede a narrative; closely related is the case of Gregory, where a list concludes and to a certain extent summarizes the historical narrative; and finally there is a fourth type, where-as in the RGDA-historical lists can function as narratives in their own right with their own specific effects on readers. Furthermore, I hope it has become clear that the question of causality is vital for both narratives and lists. One of the aims of this contribution, however, was to pave the way for a slightly broader perspective than a purely narratological one. We only understand historical lists when we also take other, perhaps less literary aspects into account. Their medium, peculiarities of their authorship and audience, and other conditions of their production, reception, and circulation all contribute to their 
complexity. Historical lists, in other words, lead a social life which demands further critical attention in current and future scholarship. ${ }^{49}$

\section{Notes}

1. For the terminology ("transformation from chronicle to story," "providing the meaning of a story = explanation as emplotment") see White 1973, 5-11 and passim.

2. On the literariness of lists see von Contzen 2016.

3. As von Contzen 2017 demonstrates, it is tempting but requires quite some modification in detail to regard lists as "simple form" in the vein of critics of literary simplicity such as Jolle, Dill, Bakhtin, and Iser.

4. For a concise survey of the more recent scholarship on the Homeric catalogue of ships see von Contzen 2016, 247-248. For lists on Greek historical inscriptions see Osbourne 2011, 103-105 and 112-118. In the Roman context-apart from the Annales Maximi to which I turn in section "History Without Rhetoric: The Annales Maximi (with Credits to Cicero)"-the consular fasti and the triumphal fasti deserve mention (see Cooley 2011, 250-251). Wiseman 2007, 70, speculates on further lists of magistrates in Rome. Finally, ancestral portrait galleries in private houses display a list-like format and commemorative practice (see Cooley 2011, 248-249). The vast galleries on the Forum of Augustus in which statues of notable men (summi viri) and mythical and historical ancestors of the gens Julia, accompanied by inscriptions, are put on display, pick up on this tradition (see Cooley 2011, 254-257 and Zanker 2009, 196-217).

5 . Both text and translation, if not otherwise indicated, are taken from Cornell 2013, abbreviated as "FRHist."

6. For a comprehensive introduction to the Annales Maximi see Rich 2013.

7. domi militiaeque gesta per singulos dies.

8. nibil potest esse ieiunius.

9. sine ullis ornamentis monumenta solum temporum, hominum, locorum, gesatrumque rerum.

10. For the Greek background see Asper 2020 with further bibliography; for Rome and especially Cicero see Berger 1978.

11. The following translations from this passage are those by Marincola 2017.

12. I borrow this formulation from Woodman 1988, 78.

13. sed iste ipse Caelius neque distinxit historiam varietate colorum neque verborum conlocatione et tractu orationis leni et aequabili perpolivit illud opus; [...] vicit tamen, ut dicis, superiores.

14. On causality/motivation as a general criterion for narrative texts see Martínez and Scheffel 2012, 111-126. 
15. et in rebus gestis declarari non solum quid actum aut dictum sit, sed etiam quo modo, et cum de eventu dicatur, ut causae explicentur omnes vel casus vel sapientiae vel temeritatis.

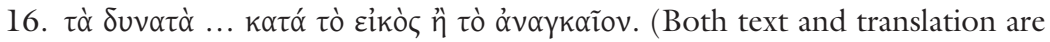
those by Halliwell 1999.)

17. See the references in Marincola's thematic index s.v. "causation (causes, consequences)," Marincola 2017, 565.

18. The Tacitus translation I give is that by Welleslay/Ash $1995 / 2009$.

19. In ann. 4.4.3-5, Tacitus has Tiberius give a speech which might serve as an interesting (but later) parallel. It is likewise positioned at the beginning of a larger section, namely the beginning of the second half of the Tiberius plot (books 1-6 of the Annales), and features a catalogue of troops, yet this time in an anti-clockwise scheme: it starts in upper Italy, Gaul, and Germany and moves to Spain, Africa, Egypt, and Syria, before ending in Thrace, Pannonia, Moesia, and finally Dalmatia.

20. sed patres laeti, usurpata statim libertate licentius ut erga principem novum et absentem; primores equitum proximi gaudio patrum; pars populi integra et magnis domibus adnexa, clientes libertique damnatorum et exulum in spem erecti: plebs sordida et circo ac theatris sueta, simul deterrimi servorum, aut qui adesis bonis per dedecus Neronis alebantur, maesti et rumorum avidi. [5] Miles urbanus ...

21. On the differentiation of "practical" versus "poetical" lists, see Eco 2009, 112-129.

22. Contra Fuhrmann 1960, 256 ("Sind auf diese Weise sämtliche Gruppen der Einwohnerschaft genannt, [...]," my italics).

23. It treats the two Mauretanias (Tingitana and Caesariensis), Raetia, Noricum, Thrace, as well as the ungarrisoned provinces and Italy itself. As Eva Noller pointed out to me, Tacitus' contemporary, the Elder Pliny, follows a similar, yet not identical scheme in the geographical books of his Naturalis Historia (3-6) in that he also starts in the west and moves eastward. Unlike Tacitus, he treats first the territories adjacent to the Mediterranean (Spain, Italy, Greece) and the more northern provinces (Gaul, Germania, Britain) only afterward; what is more, in his treatment of Africa and Asia, he does not proceed in the clockwise scheme, but again starts in the very east and moves westward.

24. See Suet. Aug. 101.4: "in the third of the three rolls, a summary of the condition of the whole empire; how many soldiers there were in active service in all parts of it, how much money there was in the public treasury and in the privy-purse, and what revenues were in arrears. He [i.e., Augustus] added, besides, the names of the freedmen and slaves from whom the details could be demanded." Tribus voluminibus, [...] tertio breviarium totius imperii, quantum militum sub signis ubique esset, quan- 
tum pecuniae in aerario et fiscis et vectigaliorum residuis. Adiecit et libertorum servorumque nomina, a quibus ratio exigi posset.

25. The fact that the breviarium was deposited with the Vestals underscores the religious connotations of this piece of writing, see Sailor 2007, 180.

26. See Damon 2003, 102 ad loc., referring to OLD s.v. ut 2 la.

27. ut non modo casus enentusque rerum, qui plerumque fortuiti sunt, sed ratio etiam causaeque noscantur.

28. Text and translations from Cooley 2009.

29. Mommsen 1887, $385=1906,247$. Quote in the original: "Wer die im Römerreich lateinisch geschriebenen Inschriften zählt, wird leicht an die hunderttausend hinankommen; wer sie wägt, dem wiegt schwerer als die zahllosen übrigen die eine, die Königin aller, das Denkmal von Ancyra."

30. Schwindt 2013, 69-76.

31. Lowrie 2009, 279-309.

32. "I gave to the people hunting shows of African wild beasts in my own name or in the name of my sons and grandsons in the circus or forum or amphitheatre twenty-six times; in these around 3,500 beasts were killed." [ven] ation [es] best [ia] rum Africanarum meo nomine aut filio $[\mathrm{ru}] \mathrm{m}$ meorum et nepotum in ci $r]$ co aut in foro aut in amphitheatris, popul[o d] edi sexiens et viciens, quibus confecta sunt bestiarum circiter tria $m[i l l]$ ia et quingentae.

33. Lowrie 2009,304 , speaks of the $R G D A$ as "a metamonument that lists all the other monuments Augustus built or restored."

34. On this aspect see Elsner 1996, 48-49 and 52.

35. See the survey in Cooley 2009, 30-41.

36. According to Suet. Aug. 85.1, this work is called De vita sua, is 13 books long, and has covered the years until Augustus' campaign in Spain in the year 25 BCE. See Malitz 2003.

37. Lowrie 2009: 279-309, and here especially 299-309 (quote on 304 and 308).

38. Kant 1793/2006, 113 (translation by Bernard 1914). Quotation in the original: "Erhaben ist das, mit welchem in Vergleichung alles andere klein ist."

39. Kant $1793 / 2006,121$ (translation by Bernard 1914). Quotation in the original: "Man sieht hieraus, daß die wahre Erhabenheit nur im Gemüte des Urteilenden, nicht in dem Naturobjekte, dessen Beurteilung die Stimmung desselben veranlaßt, müsse gesucht werden." The reason for this is that (in Kant's words) "the numerical concepts of the Understanding, by means of progression, can make any measure adequate to any given magnitude" (120). In consequence, our estimation of sublime objects is not a mathematical but an aesthetical one: Although it might be possible to comprehend something by mathematical means, the mind feels a certain 
“inadequacy" (a term Kant uses several times) of both reason and imagination when faced with objects of this kind.

40. The translations I give are those by Thorpe 1974 .

41. "We read in the consular lists that" in consularibus [sc. tabulis] legimus [...].

42. For Gregory's sources see Buchner 1990, XXV-XXX.

43. On this issue see Duchnese 1910, 283-287. See for example, the order of the bishops between Theodorus and Proculus (\#10) and Leo (\#13) which deviates from the order given in book 3; moreover, some time spans diverge, too.

44. For example, in the section of St. Martin (\#3) where Gregory mentions that Martin restored three dead people to life and stresses that "he manifests himself still today by many miracles" (et praesenti tempore multis se virtutibus declarat) or in the section on Gregory's immediate predecessor Eufronius (\#18).

45. tamen coniuro omnes sacerdotes Domini, qui post me humilem ecclesiam Turonicam sunt recturi, [...] sic numquam confusi de ipso iudicio discedentes cum diabolo condempnemini, ut numquam libros hos aboleri faciatis aut rescribi, quasi quaedam eligentes et quaedam praetermittentes, sed ita omnia vobiscum integra inlibataque permaneant, sicut a nobis relicta sunt. Quod si te, o sacerdos Dei, quicumque es, Martianus noster septem disciplinis erudiit, [...] si in his omnibus ita fueris exercitatus, ut tibi stilus noster sit rusticus, nec sic quoque, deprecor, ut avellas quae scripsi. Sed si tibi in his quiddam placuerit, salvo opere nostro, te scribere versu non abnuo.

46. For more "oral" lists, see the contribution by Lennart Lehmhaus in this volume.

47. See, for example, the study of Wiseman 2015.

48. See, for example, the review of Woodman 2015 by Feeney 2017.

49. I am grateful to Eva Noller, Cédric Scheidegger Lämmle, and Kathrin Winter, who read and commented upon earlier versions of this paper.

\section{REFERENCES}

Asper, Markus. 2020. Storytelling in Greek Law Courts. In Thinking in Cases, ed. Markus Asper, 49-66. Berlin/Boston: De Gruyter.

Baillie, John. 1747/2020. An Essay on the Sublime (published posthumously). http://sublime.nancyholt.com/Baillie/index.html. Accessed 23 Sep 2020.

Belknap, Robert E. 2004. The List. The Uses and Pleasures of Cataloguing. New Haven/London: Yale University Press.

Berger, Dorothea. 1978. Cicero als Erzähler: Forensische und literarische Strategien in den Gerichtsreden. Frankfurt/Main: Peter Lang. 
Breukelaar, Adrian H.B. 1994. Historiography and Episcopal Authority in SixthCentury Gaul: The Histories of Gregory of Tours Interpreted in Their Historical Context. Göttingen: Vandenhoeck \& Ruprecht.

Buchner, Rudolf. 1990. Gregor von Tours: Zehn Bücher Geschichten, 7th ed. Trans. W. Giesebrecht. Darmstadt: Wissenschaftliche Buchgesellschaft.

Cooley, Alison E. 2010. Res Gestae Divi Augusti: Text, Translation and Commentary. Cambridge/New York: Cambridge University Press.

- 2011. History and Inscriptions: Rome. In The Oxford History of Historical Writing. Volume 1: Beginnings to AD 600, ed. Andrew Feldherr and Grant Hardy, 244-264. Oxford: Oxford University Press.

Cornell, Tim J. 2013. Fragments of the Roman Historians. 3 volumes. Oxford: Oxford University Press. (Abbreviated as 'FRHist'.)

Damon, Cynthia. 2003. Tacitus. Histories, Book I. Cambridge: Cambridge University Press.

Duchesne, Louis. 1910. Fastes épiscopaux de l'ancienne Gaule. 2nd ed. 3 volumes. Paris: Fontemoing.

Eco, Umberto. 2009. The Infinity of Lists: From Homer to Joyce. Trans. Alastair McEwen. London: MacLehose Press.

Elsner, Jaś. 1996. Inventing Imperium: Texts and the Propaganda of Monuments in Augustan Rome. In Art and Text in Roman Culture, ed. Jaś Elsner, 32-53. Cambridge: Cambridge University Press.

Feeney, Denis. 2017. Review of Wiseman 2015. Gnomon 89: 412-418.

Fuhrmann, Manfred. 1960. Das Vierkaiserjahr bei Tacitus. Philologus 104: 250-278.

Halliwell, Stephen. 1999. Aristotle XXXIII: Poetics. 2nd ed., ed. and trans. Stephen Halliwell, 1-141. Cambridge, MA: Harvard University Press.

Hardie, Philip, ed. 2002. The Cambridge Companion to Ovid. Cambridge: Cambridge University Press.

Kant, Immanuel. 1793/2006. Kritik der Urteilskraft: Beilage: Erste Einleitung in die Kritik der Urteilskraft, 2nd ed., ed. Heiner F. Klemme. Hamburg: Felix Meiner Verlag. English edition: Kant, Immanuel. 1914. Kant's Critique of Judgement, 2nd ed. Trans. John H. Bernard. London: Macmillan.

Kloss, Gerrit. 2003. Möglichkeit und Wahrscheinlichkeit im 9. Kapitel der aristotelischen Poetik. Rheinisches Museum für Philologie 146: 160-183.

Lowrie, Michèle. 2009. Writing, Performance, and Authority in Augustan Rome. Oxford: Oxford University Press.

Mainberger, Sabine. 2013. Die Kunst des Aufzäblens: Elemente zu einer Poetik des Enumerativen. Berlin/New York: De Gruyter.

Malitz, Jürgen. 2003. Autobiographie und Biographie römischer Kaiser im 1. Jhdt. n. Chr. In Propaganda-Selbstdarstellung -Repräsentation im römischen Kaiserreich des 1. Jh.s n. Chr, ed. Gregor Weber, 227-242. Stuttgart: Franz Steiner Verlag. 
Marincola, John. 2017. On Writing History: From Herodotus to Herodian. Trans. with an Introduction and Notes by John Marincola. London: Penguin Classics.

Martínez, Matías, and Michael Scheffel. 2012. Einfübrung in die Erzähltheorie. 9th ed. Munich: C.H. Beck.

Mommsen, Theodor. 1887. Der Rechenschaftsbericht des Augustus. Historische Zeitschrift 57 = new series 21: 385-397. Reprinted in: 1906. Gesammelte Schriften, vol. 4. Berlin: Weidmannsche Verlagsbuchhandlung, 247-258.

Osbourne, Robin. 2011. Greek Inscriptions as Historical Writing. In The Oxford History of Historical Writing. Volume 1: Beginnings to AD 600, ed. Andrew Feldherr and Grant Hardy, 97-121. Oxford: Oxford University Press.

Rich, John W. 2013. Annales Maximi. In The Fragments of the Roman Historians, ed. Tim J. Cornell, vol. 1, 141-159. Oxford: Oxford University Press.

Sailor, Dylan. 2007. Writing and Empire in Tacitus. Cambridge: Cambridge University Press.

Schmal, Stefan. 2011. Tacitus. 3rd ed. Hildesheim/Zürich/New York: Georg Olms Verlag.

Schwindt, Jürgen Paul. 2013. Der Sound der Macht: Zur onomatopoetischen Konstruktion des Mythos im Zeitalter des Augustus. In La costruzione del mito augusteo, ed. Mario Labate and Gianpiero Rosati, 69-87. Heidelberg: Universitätsverlag Winter.

Stäheli, Urs. 2011. Das Soziale als Liste: Zur Epistemologie der ANT. In Die Wiederkehr der Dinge, ed. Friedrich Balke, Maria Muhle, and Antonia von Schöning, 83-101. Berlin: Kulturverlag Kadmos.

- 2016. Indexing-The Politics of Invisibility. Society and Space 34 (1): 14-29.

Syme, Ronald. 1958. Tacitus. Oxford: Oxford University Press.

Thorpe, Lewis. 1974. Gregory of Tours: The History of the Franks. Trans. Lewis Thorpe. London: Penguin Classics.

von Contzen, Eva. 2016. The Limits of Narrativity: Lists and Literary History. Style 50: 241-260.

- 2017. Grenzfälle des Erzählens: Die Liste als einfache Form. In Komplexität und Einfachbeit, ed. Albrecht Koschorke, 221-239. Stuttgart: J.B. Metzler.

Wellesley, Kenneth, and Rhiannon Ash. 2009. Tacitus: The Histories. 2nd ed. Trans. Kenneth Wellesley. London: Penguin Classics.

White, Hayden. 1973. Metahistory: The Historical Imagination in NineteenthCentury Europe. Baltimore: Johns Hopkins University Press.

Wiseman, Timothy Peter. 2007. The Prehistory of Roman Historiography. In $A$ Companion to Greek and Roman Historiography, ed. John Marincola, 67-75. Malden: Wiley-Blackwell. 
2015. The Roman Audience: Classical Literature as Social History. Oxford: Oxford University Press.

Woodman, Anthony J. 1988. Rhetoric in Classical Historiography: Four Studies. London/Sydney/Portland: Taylor \& Francis.

. 2009. Introduction. In The Cambridge Companion to Tacitus, ed. Anthony J. Woodman, 1-14. Cambridge: Cambridge University Press.

Zanker, Paul. 2009. Augustus und die Macht der Bilder. 5th ed. Munich: Verlag C.H. Beck.

Open Access This chapter is licensed under the terms of the Creative Commons Attribution 4.0 International License (http://creativecommons.org/licenses/ by $/ 4.0 /$ ), which permits use, sharing, adaptation, distribution and reproduction in any medium or format, as long as you give appropriate credit to the original author(s) and the source, provide a link to the Creative Commons licence and indicate if changes were made.

The images or other third party material in this chapter are included in the chapter's Creative Commons licence, unless indicated otherwise in a credit line to the material. If material is not included in the chapter's Creative Commons licence and your intended use is not permitted by statutory regulation or exceeds the permitted use, you will need to obtain permission directly from the copyright holder.

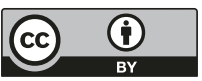

